\title{
Dakwah Islam Multikultural Pada Komunitas Sunda, Arab Alawi dan Arab Irsyadi
}

\author{
Sukriadi Sambas ${ }^{1 *}$, Indira Sabet Rahmawaty ${ }^{1}$, Ratna Dewi ${ }^{2}$ \\ ${ }^{1}$ Fakultas Dakwah dan Komunikasi \\ Universitas Islam Negeri Sunan Gunung Djati, Bandung \\ *synkriadisambas@gmail.com
}

\begin{abstract}
The characteristics of Islam as a religion of da'wa makes Islam capable of crossing the walls of diversity in society, creating harmony, providing solutions to diversity and even conflict. This multicultural aspect can be seen in the meeting of the elements of da'wa: da'i, mad'u, messages and media of da'wa. The multiculturalist aspect is examined qualitatively descriptive in the process of dakwah in the Sundanese community, Alawi Arabs and Irsyadi Arabs. The Sundanese, Arab Alawi and Arab Irsyadi communities are qualified as competent da'i. Scientific competence is symbolized in the title carried by da'i. This title is one of the important factors in the image of da'i. The da'i title is Kyai, Ajengan and the teacher for the Sundanese community; Habib, Syarif and Sayid for the Arab Alawi community; and an academic degree for the Irsyadi Arab community. If all communities appreciate the differences shown by the respective communities. Mad'u from three communities mingled at the same time and place in certain da'wa events, and parted ways in a typical community events. Da'wa messages delivered by the three communities are the same and some are unique. But the source of the message is the same, namely Al-Quran and As-Sunnah. For the Irsyadi Arab community Ijma and qiyas were not added except for the Sundanese and Alawi Arabs. Wasilab (media) propaganda is the same except the Irsyadi Arab community does not use media in its opinion including bid'ah and khurafat.
\end{abstract}

Keywords: Da'wa; Multikulturalism; Sunda; Arab Alawi; Arab Irsyadi.

\begin{abstract}
ABSTRAK
Karakteristik Islam sebagai agama dakwah membuat Islam mampu melintasi dindingdinding keragaman masyarakat, mewujudkan keharmonisan, memberi solusi atas keragaman bahkan konflik. Aspek multikultural ini terlihat dalam pertemuan unsur-unsur dakwah: da'i, mad'u, pesan dan wasilah dakwah. Aspek multikulturalis diteliti secara kualitatif deskriptif dalam proses dakwah di komunitas Sunda, Arab Alawi, dan Arab Irsyadi. Da'i komunitas Sunda, Arab Alawi, dan Arab Irsyadi memiliki kualifikasi sebagai da'i yang kompeten. Kompetensi keilmuan disimbolkan dalam gelar yang disandang da'i. Gelar ini menjadi salah satu faktor penting citra da'i. Gelar da’i yaitu Kyai, Ajengan dan pak guru bagi da'i komunitas Sunda; Habib, Syarif dan Sayid bagi da'i komunitas Arab Alawi; dan gelar akademik bagi da'i komunitas Arab Irsyadi. Da'i semua komunitas menghargai perbedaan yang ditunjukan uruf masing-masing komunitas. Mad'u dakwah dari tiga komunitas berbaur pada waktu dan tempat yang sama dalam event-event dakwah
\end{abstract}

Diterima: Bulan Tahun. Disetujui: Bulan Tahun. Dipublikasikan: Bulan Tahun 
tertentu, dan berpisah dalam event dakwah khas perkomunitas. Pesan dakwah yang disampaikan da'i ketiga komunitas ada yang sama dan ada yang khas. Namun sumber pesannya sama, yaitu Al-Quran dan As-Sunah. Bagi komunitas Arab Irsyadi tidak ditambah ijma dan qiyas kecuali bagi komunitas Sunda dan Arab Alawi. Wasilah (media) dakwahpun sama kecuali komunitas Arab Irsyadi tidak menggunakan media yang dalam pendapatnya termasuk bid'ah dan khurafat.

Kata kunci : Dakwah; Multikulturalisme; Sunda; Arab Alawi; Arab Irsyadi

\section{PENDAHULUAN}

Keragaman, kepluralan atau kebhinekaaan adalah hal yang telah menjadi ciri dari negara Indonesia. Penduduk yang mayoritasnya muslim tidak membuat masyarakat Indonesia hanya memiliki 1 (satu) warna budaya namun ada banyak warna yang muncul. Inilah yang menjadikan Indonesia layak disebut sebagai negeri muslim yang memiliki keragamaan budaya atau multikultural. Penerimaan Islam yang baik secara umum menurut Dr. Syauqi Abu Khalil adalah karena faktor keberhasilan dakwah dan sebab tersebarnya islam adalah kesederhanaan akidah Islam merupakan faktor utama keberhasilan dakwah.

Kesederhanaan dalam arti tidak ada sesuatu yang menyulitkan dan juga sesuatu yang mengharuskan untuk tunduk kepada perkara yang tidak rasional. Islam adalah akidah yang mudah dipahami dan dapat diterima oleh manusia biasa, juga terhindar dari segala tipu daya teori ketuhanan. Ia adalah akidah yang dapat dijelaskan oleh siapapun, bahkan oleh orang yang minim pengalaman sekalipun dalam istilah-isltilah agama.Akidah islam yang rasional benar-benar telah melahirkan kekaguman bagi semua orang. Akidah islam adalah akidah yang memliki kekuatan yang sangat besar untuk membuka pintu hati semua orang, akidah yang mengerahkan kekuatan kaum muslimin untuk melakukan pembebasan tanpa pemaksaan. (2012: 273).

Thomas W Arnold (1970) menyatakan bahwa perkembangan Islam di Indonesia khusus Jawa tidak bisa dilepaskan dari pertemuan Raja Jawa dengan para pedagang Arab. Peran bangsa Arab atau orang keturunan Arab ini terlihat dalam konteks dakwah di Indonesia. Hal ini seperti yang dikatakan Hamka (1961) bahwa orang Arab adalah pelopor Islam, mereka telah datang ke negeri-negeri Melayu pada abad ke VII M, atau tahun pertama Islam. Dengan demikian, sejarah masuknya Islam ke Indonesia terutama sejarah perkembangannya tidak terlepas dari sejarah masuknya perantau Arab di Indonesia. Keturunan Arab Hadramaut di Indonesia, seperti negara asalnya Yaman, terdiri 2 kelompok besar yaitu kelompok Alawi atau Sayyidi, dan kelompok Qabili. Di Indonesia, kadang-kadang ada yang membedakan antara kelompok Sayyidi yang umumnya pengikut organisasi Jamiat al-Kheir, dengan kelompok Syekh atau Masyaikh yang biasa pula disebut Irsyadi atau pengikut organisasi al-Irsyad. Bukti membaurnya komunitas 
Arab dengan pribumi Indonesia terlihat dari adanya berbagai perkampungan Arab yang banyak tersebar di berbagai kota di Indonesia.

Oleh karena itu, maka terjadilah sebuah proses asimilasi yang disebabkan hubungan interaksi sosial antar masyarakat pribumi dengan masyarakat asing yang juga mempengaruhi budaya dan bahasa antar keduanya. Keunikan model dakwah Islam ini juga nampak dalam kehadiran komunitas Arab Alawy dan Arab Irsyady di tengah-tengah masyarakat Sunda khususnya di Empang Kota Bogor. Kehadiran komunitas Arab Alawy dan Irsyady yang mengidentifikasikan dirinya sebagai keturunan Rasullullah saw memposisikan komunitas Arab ini dalam posisi yang dihormati bahkan dimuliakan. Salahsatu tokohnya adalah Al-Allamah AlImam Al-Sayyid Abdullah bin 'Alawi Al-Haddad adalah seorang ahli dakwah, sufi, mursyid, imam zamannya yang selalu berjuang demi membela agama Islam yang suci dengan lisan dan perannya, yang menjadi tumpuan dan rujukan masyarakat dalam menuntun ilmu pengetahuan. Beberapa karya beliau adalah Al-Nasha'ih AlDiniyyah, Al-Da'wah Al-Tammah, Risalah Al Mudzakarah, Sabil Al-Idzkar (yang telah diterjemahkan kedalam bahasa Indonesia dengan judul Renungan tentang umur manusia, diterbitkan oleh mizan, Bandung), dan buku Meraih Kebahagiaan Sejati: jalan Hidup Para Nabi dan Orang Suci (1392 H, Judul Aslinya Al-Ushul AlIlmiyyah wa Al-Ushul AlHukmiyyah).

Kekhasan dakwah yang dilakukan komunitas Arab ini, selain dengan mendirikan mesjid memang dalam bentuk buku yang mengenalkan bacaan-bacaan doa dan pujian yang dihimpun dalam ratib. Daya tarik dari tradisi membaca ratib dan meminta doa dari Ulama keturunan Nabi inilah yang membuat sebagian besar komunitas sunda banyak mengikuti berbagai kegiatan dari komunitas Arab ini. dakwah Islam kultural dan multikultural inilah yang menjadi fokus dalam penelitian ini dan diharapkan mampu menjadi salahsatu model dakwah yang bisa diterapkan dan dikembangkan di wilayah-wilayah lainnya. Berdasarkan latar belakang di atas maka rumusan masalah dalam penelitian ini difokuskan pada kualifikasi proses dakwah oleh komunitas Sunda, Arab Alawi dan Arab Irsyadi sebagai solusi konflik, yang meliputi: Pertama, Kualifikasi Dai komunitas Sunda, Arab Alawi dan Arab Irsyadi. Kedua, Kualifikasi Mad "e komunitas Sunda, Arab Alawi dan Arab Irsyadi. Ketiga, Kualifikasi Pesan Dakwah komunitas Sunda, Arab Alawi dan Arab Irsyadi. Keempat, Kualifikasi Metode dan Media Dakwah komunitas Sunda, Arab Alawi dan Arab Irsyadi

Beberapa penelitian sebelumnya dengan tema dakwah multikultural bisa ditelusuri. Misalnya Penelitian Usfiyatul Marfu'ah dengan judul Strategi Komunikasi Dakwah berbasis Multikultural (2017). Diawali dengan posisi kondisi multikultural yang digambarkan seperti dua mata pisau: sebagai kekayaan namun potensi konflik di sisi yang lain. Maka penelitian ini menunjukkan pentingnya strategi komunikasi dakwah dengan pendekatan multikulturalisme yang akan 
mencari titik temu dalam keragaman dan toleransi dalam perbedaan. Penelitian yang lain dengan pendekatan normatif tekstual ditulis oleh Heru Suparman dengan judul Multikultural dalam Alqur'an (2017) yang menegaskan Alqur'an memberikan landasan dan panduan dalam menghadapi kondisi multikultural ini. Penelitian lain yang sewarna diantaranya dilakukan Nawawi (2012) dengan judul Dakwah dalam Masyarakat Multikultural, kemudian Rosidi (2017) dengan judul Metode Dakwah Masyarakat Multikultural di Indonesia. Penelitian yang lain oleh Saifulah (2014) dengan judul Dakwah Multikultural Pesantren Ngalah dalam Meredam Radikalisme Agama juga Turhamun (2016) dengan Multikulturalisme sebagai Realita dalam dakwah. Hasil penelitian Turhamun menyatakan bahwa strategi dakwah (bi al-kitabah, bi al-lisan, bi al-hal) kiranya masih cukup relevan untuk diterapkan pada era multikulturalisme, yang menjadi penting adalah bagaimana pengembangannya serta implementasinya supaya tidak hanya mengenai doktrin keagamaan melainkan lebih ke persoalan sosial. Namun dalam penelitianpenelitian tersebut belum ada yang spesifik meneliti aspek dakwah multikulturalisme dalam masyarakat dimana komunitas Sunda-Arab Alawi-Arab Irsyadi bertemu.

Berdasarkan paparan di atas, penelitian ini bertujuan untuk mendapatkan deskripsi tentang kualifikasi dai, kualifikasi mad ${ }^{e e} u$, kualifikasi pesan dakwah dan kualifikasi metode dan media dakwah dari 3 komunitas yaitu komunitas Sunda, Arab Alawi dan Arab Isryadi di Kampung Arab Empang Kecamatan Bogor Selatan Kota Bogor Propinsi Jawa Barat. Penelitian ini juga bertujuan untuk menunjukkan dan menggambarkan bahwa model dakwah multikultural adalah salahsatu solusi konflik atau potensi konflik di tengah masyarkat yang plural. Adapun penelitian ini diharapkan memberi manfaat dalam memberikan pemahaman bahwa keragaman, perbedaan warna kulit, suku, bahasa, paham agama, dan budaya tidak selamanya menjadi sumber konflik, perpecahan, dan perkelahian, tetapi dapat menjadi perekat terwujudnya kesatuan dalam keragaman. Apalagi terhadap penyampaian dakwah multikultural baik dari dai maupun mad'u dapat menghargai dan menerima perbedaan terutama terkait isi pesan dakwah yang disampaikan oleh dai dari setiap komunitas

Metode penelitian yang digunakan adalah metode penelitian kualitatif deskriptif-analistis dengan menggunakan berbagai informasi dan data dari para narasumber yang mewakili 3 (tiga) komunitas: Arab Alawy, Arab Irsyadi dan Sunda. Informasi dan data yang ada dihimpun, dipilah, disusun dan selanjutnya diberikan analisis-deskriptif dengan menggunakan berbagai pandangan, konsep dan teori tentang dakwah multikultural. Sebagaimana yang Judistira K. Garna menyatakan (2009:226) bahwa dalam penelitian kualitatif ini, peneliti merupakan instrumen dalam penelitian yang mengumpulkan data dan dianalisis secara induktif, kemudian menjelaskan proses yang diteliti secara ekspresif. Sifat manusia 
yang dinamik dan berkemauan bebas serta prilaku etnik Sunda, Arab Alawy, Arab Irsyadi yang unik dan khas lebih tepat diekplorasi dengan menggunakan paradigma penelitian subjektif atau kualitatif, atau disebut sebagai paradigma naturalistik yang sesuai dengan tujuan penelitian ini. Pengumpulan data di dapatkan dengan wawancara mendalam (indepth interviews) dengan para tokoh atau pengurus dari tiap komunitas, wawancara kelompok (group interviews), Observasi dan partisipasi aktif dan studi kepustakaan. Observasi dan partisipasi aktif dilakukan dengan terlibat kegiatan di lingkungan mad'u etnik Sunda, Arab Alawy dan Irsyadi sehingga peneliti mampu melihat kesesuaian berbagai penelitian sebelumnya juga hasil wawancara dengan tingkahlaku nyata di konteks tertentu. Dengan observasi juga memungkinkan peneliti menangkap berbagai hal baru atau sisi lain dari objek penelitian yang belum terungkap sebelumnya.

\section{HASIL DAN PEMBAHASAN}

Sebagaimana dijelaskan dalam pendahuluan bahwa proses dakwah adalah aspek yang akan dijelaskan dalam tulisan ini. Proses dakwah ini mencakup unsur-unsur dakwah yaitu da'i, mad'u, pesan, metode dan media dakwah dalam 3 (tiga) komunitas yaitu Sunda, Arab Alawi dan Arab Irsyadi.

\section{Unsur Da'i Komunitas Sunda, Arab Alawi dan Arab Irsyadi}

Unsur Da'i dakwah dalam Komunitas Sunda di kelurahan Empang sudah hadir sebelum datangnya mubaligh dari Arab Yaman yang datang ke wilayah Empang Bogor yaitu Habib Alwi bin Ismail Al-Idrus tahun 1972 M. Da'i dari komunitas Sunda Empang tersebut bernama Rd. H.Thahir yang telah mendirikan mesjid dengan arsitektur kesundaan (Bangunan Joglo). Mesjid memang menjadi pusat dari berbagai kegiatan dakwah yang mempertemukan da'i dan mad'u dari ketiga komunitas ini. Komunitas Sunda menjadikan Mesjid Agung Ath-Thohiriya sebagai pusat kegiatan dakwah mereka. Dakwah di lakukan oleh Da'i dari etnik Sunda dan juga menghadirkan Dai dari kalangan Arab Alawi pula.

Da'i kalangan Sunda juga ada da'i yang ditugaskan untuk menjadi mujawir (Kuncen) makam Raden Dalem Shalawat dan mujawir ini merupakan keturunan dari Raden Dalem Shalawat. Bertugas untuk memelihara kebersihan makan dan membantu orang-orang yang ingin berziarah dan berdoa dimakam keramat tersebut dan berharap memperoleh barakah agar do'a penziarah dikabulkan oleh Allah SWT. Adab dan tatacara ziarah mengikuti kebiasaan paham Suni Khalafi sebagaimana yang biasa dibacakan di acara tahlilan oleh keluarga yang ditinggalkan wafat dan dibantu oleh kerabat dan tetangga yang sepaham.

Bagi kalangan komunitas Arab Alawi, yang kegiatan dakwahnya dipusatkan di Mesjid Keramat Noer Alatas dan membentuk yayasan yaitu yayasan mesjid noer alatas. Komunitas Arab Alawi tidak eksklusif, mereka membuka kesempatan bagi dai komunitas Sunda, terutama yang ditugasi untuk dakwah lewat 
pendidikan sekolah.

Sedangkan da'i dari silsilah Arab Alawi adalah Habib Al-Athas (Wafat, 1933 M). Beliau berasal dari Yaman Selatan atau Hadromaut yang beraliran mazhab Suni/Ahlus Sunnah wal Jama ${ }^{e e}$ ah. Di Yaman sendiri ada 2 (dua) aliran mazhab (Sekte) Islam yaitu Yaman Selatan bermazhab Suni sedangkan Yaman Utara bermazhab Syi ${ }^{\text {ec }}$ (Tidak disebutkan faksi syi ${ }^{\text {ee }}$ yang mana). Sekarang di tahun 2016 pengelolaan institusi Mesjid Agung At-Thohiriyah ini dilakukaan oleh 2 (dua) institusi Yayasan At-Thohiriyah dan kepengurusan Dewan Kemakmuran Mesjid (DKM) Mesjid At Thahiriyah.

Alawi sendiri atau 'Alawiyin itu dimaksudkan kepada 'Ali dan Fatimah, susun galur semua keturunan dari Hasan dan Husen putra dari perkawinan Ali dan Sayidah Fatimah, sebagai cucu dari Nabi Muhammad saw disebut juga sebagai „Izzati Ahli Bait. Leluhur Arab 'Alawi bertempat tinggal di Bayhrah Irak, tersebutlah nama tokoh Imam Al-Muhajir ibn Isa al-'Alawi (Tahun 273 H), beliau dalam perjalanan hidupnya melakukan migrasi ke Hidramaut, negeri Yaman, dan bermukim di Yaman Selatan. Dan migrasi ini merupakan migrasi gelombang kedua setelah gelombang pertama gerakan penyebaran Islam ke Yaman. Banyak faktor yang menjadi penyebab terjadinya migrasi gelombang kedua tersebut antara situasi politik dan penguasanya kelahiran Khawarij, Dari keturunan Imam Muhajir adalah Sayid Imam Abdullah Ibnu 'Alawi al-Hadad al Husaini yang berdakwah masuk ke Nusantarapada ke 16 M. Beliau berpaham mazhab Ahlus Sunnah wal Jamaah, dalam bidang Tauhid mengikuti mazhab Asy'ari dan Maturidi, dalam bidang Fiqih mengikuti Mazhab Imam Safi'i. Kemudian, dari keturunan Abdullah bin Alwi al-Hadad ada yang berkiprah melakukan dakwah ke wilayah Bogor dan tempat yang dituju adalah Empang Bogor, dan di Empang ini sudah ada tokoh penyebaran Islam, yaitu Embah Sholawat. Mereka adalah Habib Alwi bin Ismail Al-Idrus (W. 1931 M), Habib Al-Athas (W. 1933 M), dan Habib Abdullah As-Syaf (W. 1937 M). Mereka dimakamkan di Empang Bogor Jl. Lolongar.

Para da'i yang beretnik (syu"ub, qabail) Arab memiliki motivasi dan karaktersitik mental migrasi (riblah/hijrah) sebagai implementasi dari perintah ajaran Islam yang tersurat dalam AlQuran khususnya surat Al-Quraisy. Itulah karakteristik utama para da'i yang disebut dengan Arab Alawiyyin dan Arab Irsyadi (yang mengikuti gerakan pembaruan Islam). Orang-orang Indonesia mengenal da'i-da'i dari Alawiyyin ini dengan sebutan "wali-wali". Sedangkan di Jawa khususnya mereka dikenal dengan nama "Sunan".

Komunitas Arab Irsyadi berasal dari susur galur leluhur yang sama dengan komunitas Arab Alawi, namun mereka beralih haluan dalam hal aktivitas dakwah sebagai pengamalan syariat islam dari suni tradisional kepada "suni moderen" (gerakan pembaharuan islam, gerakan pemurnian aqidah) Tokoh utama pembawa gerakan ini mendirikan Jamiat Khair pada tahun 1905 M, pendirinya berasal dari 
keturunan Arab Hadramaut KH. Ahmad Dahlan dan H.O.S. Cokroaminoto tercatat sebagai anggota organisasi.

Kemudian pada tahun 1914 M didirikanlah yayasan islam Al-Irsyad, tokoh pendirinya selain Ahmad Surkati adalah Umar Manqus, Salim Abdad, Salim Balfas, Abdullah Harkarah, Umar al-Nandi. Dengan demikian, Arab Irsyadi adalah individu-individu Arab muslim yang berpaham dan mengekspresikan kegiatan keberagamaannya menurut konsep pembaharuan islam dan bergabung menjadi jama'ah organisasi Al-Irsyad Al-Islamiyah. Nama mesjid yang dimiliki oleh Jama'ah Arab Irsyadi adalah AlTaqwa, Komunitas Arab Irsyadi berbeda dengan Arab Alawi dan komunitas Sunda.

Para da'i dari Arab Irsyadi ini berada di bawah organisasi Jamiyah al-Irsyad. Tidak ada sebutan habib di kalangan komunitas Arab Irsyadi, mereka tidak mempersoalkan marga, unsur gelar keturunan. Memang, bagi Jamiyah Al-Irsyadi ini sesuai dengan historis pendirinya, yaitu syekh Ahmad Surkabi yang dari Yaman juga, tetapi sudah mengikuti paham gerakan modernisasi Islam atau pembaruan Islam yang dipelopori gerakan wahabiyah, Jamaludin Al-Afghani dan syeikh Muhammad Abduh.

Pengisi Ta'mir Masjid Al-Taqwa milik Jamiyah Al-Irsyad di isi oleh namanama da'i komunitas tersebut. Walaupun demikian komunitas Arab Irsyadi, juga tidak eksklusif, mereka memberi kesempatan yang leluasa kepada da'i-da $i$ dari komunitas Sunda, bagi da'i komunitas Sunda disebut Kiayi atau Ajengan, da’i Arab Alawi disebut habib, sedangkan Arab Irsyadi menggunakan gelar kesarjanaan/akademik pendidikan tinggi yaitu sarjana dan pascasarjana.

\section{Unsur Mad'u Komunitas Sunda, Arab Alawi dan Arab Irsyadi}

Unsur mad'u atau para jama'ah lebih banyak dari komunitas Sunda dibanding komunitas Arab Alawi. Jamaah komunitas Sunda berasal dari wilayah Kabupaten Bogor dan sekitarnya. Mereka menghadiri ta'lim sekalian tabaruk berziarah ke maqam Habaib.

Mad'u komunitas Arab Alawi memiliki tradisi yang berbeda dengan komunitas Sunda ketika berkelompok secara homogen., cara berpakaian yang khas orang Arab: Laki-laki menggunakan gamis atau jubah dan warna yang dipilih kebanyakan berwarna putih. Tingkatan umur, pengetahuan, status dan pekerjaan komunitas Arab Alawi adalah heterogen. Heterogenitas ini menjadi aset komunitas Arab Alawi yang tetap terjalin keakraban karena adanya ikatan keetisan sebagai orang keturunan Arab dan ikatan kesamaan pilihan warna dan corak pemahaman keagamaan yaitu Suni khalafi atau ahlus Sunnah wal Jama'ah.

Kemudian dalam kegiatan ta'lim, tabligh akbar yang diselenggarakan oleh komunitas Arab alawi juga diikuti komunitas Sunda. Dalam suatu pengajian, mereka bersatu dan membaur tidak memperlihatkan sesuatu yang eksklusif. Hal 
yang demikian diperlihatkan ketika penyelenggaraan kegiatan ta ${ }^{e c} \mathrm{lim}$, peringatan hari-hari besar, majelis dzikir, halaqah Ratiban (khusus dzikir dengan teks du ${ }^{\text {ee }}$ ratib).

Mad'u juga hadir dalam bentuk dakwah lewat media sekolah ibtidaiyah tsanawiyah dan Aliyah, juga diikuti oleh anak-anak komunitas Arab Alawi dan komunitas sunda. Mereka berasal dari wilayah Empang dan ada juga dari luar wilayah Empang, terutama yang orangtua peserta didik sekolah tersebut adalah para pengikut para habaib.

Tingkat pemahaman keagamaan mad ${ }^{e e} u$ komunitas Arab Alawi termasuk kategori yang bukan cendekia juga bukan bodoh tetapi sama dengan komunitas Sunda yaitu kelompok awam (Tingkat pemahaman yang belum mencapai tingkat cendekia). Namun demikian dalam event event tertentu diikuti oleh mad ce yang bukan awam, seperti para ustadz, kyai, guru-guru ngaji yang ingin bertabaruk (ngalap barokah) ketika dainya adalah habaib yang sudah terkenal. Misalnya dalam event peringatan hari-hari besar Islam dan event halaqah dzikir yang menggunakan teks dzikir atau dua ratib.

Mad'u dari komunitas Arab Irsyadi ada yang homogen dari kalangan Arab Irsyadi yaitu ketika penyelenggaranya di lingkungan dan rumah tangga mereka. Namun ketika penyelenggaraan dakwah berupa ta'lim dan pendidikan formal atau sekolah diikuti oleh selain anak-anak Arab Alawi dan anak-anak komunitas Sunda. Mad'u dari komunitas Arab Irsyadi agak berbeda dengan komunitas Arab Alawi dan komunitas Sunda. Mereka kebanyakan awam yang mengarah pada para cendikia yang ditandai dengan sikap kritis . Tradisi kritis menjadi ciri dari mad'u komunitas Arab Irsyadi. Hal ini terjadi karena dai dan pesan dakwah yang disampaikannya bercorak berbeda dengan apa yang tersajikan di kalangan mad'u dari komunitas sunda dan Arab Alawi terutama mad'u dari anggota Jam iyah Al Irsyadiyah.

Mad'u yang beretnik Sunda lebih dominan sedangkan dari etnik Arab Alawi dan Irsyadi proporsinya lebih sedikit. Misalnya dalam aktivitas shalat wajib jum'at, shalat wajib lima waktu dan shalat tarawih yang sempat peneliti amati. Keikutsertaan dalam ta'lim juga lebih banyak diikuti oleh etnik sunda dari kalangan jamaah perempuan. Jama'ah laki-laki dari etnik sunda lebih banyak dan dari Arab baik Arab alawi maupun Irsyadi lebih sedikit. Tiga agrerat warna etnik ini membaur bersatu dalam satu majelis.

\section{Unsur Pesan Dakwah Komunitas Sunda, Arab Alawi dan Arab Irsyadi}

Pesan dakwah secara umum meliputi: Pertama, ajaran yang berupa ushuliyah (pilar dan kerangka dasar atau pokok utama) sebagaimana diisyaratkan dalam Q.S.AlBaqarah, 2: 177. Kedua, karakteristik pesan dakwah yang diistilahkan Al-Quran 
sebagai syariah, washiyah Allah, Shirath mustaqim, Din Qayim, dan Milah Ibrahim.

Warna dan corak pilihan pemahaman keislaman mereka adalah Suni Khalafi atau Ahlu Sunnah wal Jama "eah dalam versi yang berbeda dengan warna dan corak pemahaman penganut pemahaman suni salafi atau gerakan pemurnian ajaran Islam. Tradisi kesundaan yang merupakan ekspresi keberagamaan masih dipraktikan. Misalnya, upacara tahllilan, syukuran-syukuran dalam siklus kehidupan masih dipraktikan. Walaupun demikian komunitas sunda tidak menampakkan sikap dan perilaku konflik terhadap sikap dan perilaku yang berbeda. Yaitu diperlihatkan oleh suni salafi yang dianut oleh Arab Irsyadi dan sebaliknya.

Pesan dakwah yang disajikan di kalangan komunitas sunda oleh para dai, menurut corak dan warna pemahamannya adalah ajaran Islam Sunni Khalafi atau Ahlus Sunnnah Wal Jamae ah yang menurut sumbernya adalah Al Qurean dan Al Hadits, Ijma dan Qiyas yang berhhubungan dengan ajaran pokok (ushuliyah) dan ajaran cabang (Furuiyah).

Aspek ajaran Ushuliyah (ajaran pokok) yang berkaitan dengan aqidah yang dianut oleh da'i dan mad'u komunitas Sunda, yaitu madzhab Ahli sunah wal Jama'ah. Menurut sumbernya dalam aspek aqidah digagas oleh Imam abdul Hasan al-Asy'ari dan Abu Mansyur Al-Maturidi, walaupun inti ajaran aqidah ini tidak langsung merujuk karya penggagas paham Ahlus Sunah wal Jama'ah, misalnya kitab Maqalatul-Islamiyin Fi Ikhtilafil-Mushalin, tetapi merujuk karya-karya yang ditulis oleh ulama pengikut beliau. Antara lain kitab Tijan Ad-Durari karya Imam Ibrahim al-Bajuri dan Perukunan karya syeikh al-Arsyad Al-Bajari dalam bahasa melayu dan dialih bahasakan ke dalam bahasa Indonesia oleh KH. Muhammad Abdullah bin Hasan pengasuh pondok pesantren Darus-Saa'dah Cikaroya Cisaat Sukabumi tahun 1414, dengan judul Perukunan Gede Kumlit, menggunakan bahasa Sunda dengan tulisan huruf Arab Pegon.

Pesan dakwah yang bersumber dari kitab tersebut yang biasa disampaikan kepada kelompok jama'ah awam. sedangkan materi aqidah untuk peserta didik anak-anak (mad'u di lingkungan madrasah diniyah) aenggunakan hapalan AlAsmaul Husna. Modifikasi tambahan sumber mengenai aqidah biasanya disampaikan oleh para da'i menurut pengalaman bacaan masing-masing mengenai aqidah Ahlus Sunah Waljama'ah, baik dalil-dalil Al-Quran maupun alHadits, halhal yang terkait dengan macam fiqroh Teologis (bidang aqidah), mereka masih belum banyak mengetahui, yang mereka klaim adalah Firqah Ahlus Sunah Waljama'ah sebagai firqah Najiyah (golongan keyakinan yang akan memperoleh keselamatan), mereka hanya mengetahui dan mengklaim Suni dan Non Suni.

Aspek ajaran Furu'iyah, yaitu mengenai bidang ibadah mahdhah dan ghoir mahdhah, mereka.menggunakan Fiqih madzhab Imam Syafi'i, walaupun 
tidak.bersumber langsung dari karya imam Syafi'i, misalnya kitab al-Umm, karya monumental beliau, tetapi menggunakan karya-karya ulama pengikut madzhab Imam Syafi'i, yaitu antara lain kitab Kasyifatus Saja bi Syarh Safinatun-Naja, biasa disebut kitab Safinah, syarah karya Syeikh Nawawi Banten. Oleh Karenanya, dalam hal pelaksanaan ibadah sebagai pengamalan dari rukun islam, sangat kental bercorak tradisi ibadah yang diklaim sebagai tradisi Ahlus-Sunah Waljama'ah, sesuai dengan.pesan dakwah bidang fiqih yang disampaikan oleh para da'i.

Aspek ajaran akhlak, pesan dakwah yang disampaikan, pada umumnya mengacu pada karya Syeikh Nawawi Banten, yaitu kitab Miraq al-ubudiyah syarh Bidayah al Hidayah karya Imam al-Ghazali. Sedangkan kitab Ibya 'Ulumuddin karya monumental dan komprehensip tentang akhlak hanya ditujukan kepada mad'u yang bukan kelompok awam (mayoritas mad'u yang berpengetahuan belum sampai ada peringkat cendikia). Bagi mad'u anak-anak peserta didik diniyah mengikuti dan mengacu pada kurikulum yang dikeluarkan oleh Kementrian Agama RI, yang menurut corak pemahamannya, masih cenderung bercorak pemahaman suni.

Pesan dakwah bagi komunitas Arab Alawi selain banyak kesamaan

dengan pesan dakwah yang disampaikan oleh da'i komunitas Sunda, ada beberapa pesan dakwah yang khas disampaikan oleh para da'i komunitas Alawiyin yaitu, dalam hal aspek aqidah, mereka lebih banyak merujuk pada sumber ajaran Suni yang disusun oleh leluhur mereka, misalnya, kitab matan Syafinatun Naja Fi shulud-Din wal-Fiqh karya Sali ibn Samir al-Hadrami yang bermazhab Imam Syafiei, dan kitab al-Riyadh al Badi'ah Fi Ushuluddin.

Al-Hadrami adalah nisbah bagi asal tanah air leluhur Arab Alawi, yaitu Hadramaut Yaman. Kitab yang sama, juga dijadikan rujukan dalam hal ajaran furu mengenai ibadah mahdhah. Sedang sumber lain yang digunakan mengenai fiqh adalah kitab karya Al-Ba'asyir, yaitu kitab Busyral Karim Fi Masail al-Ta"lim, kitab ini menjelaskan tentang aqidah, ibadah, dan akhlak, beliau masih keturunan dari jalur leluhur Arab Alawi. Dalam bidang akhlak, mereka juga menggunakan kitabkitab yang ditulis oleh da'i yang ulama dan ulama yang da'i dari Arab Alawi. Misalnya kitab al-Muawanah, dan kitab ad-Da"watut-Tamah, kitab yang disebut terakhir ini, selain memuat ajaran akhlak juga memuat kode etik dakwah dengan mengategorikan da'i dan mad'u dari status sosialnya. Misalnya ada mad'u kalangan Umaro (pemerintahan), maka tidak heran jika dari Habaib yang banyak menyampaikan Nasihatul-Muluk (kritik yang bersifat nasehat kepada para pejabat). Mereka, sama dengan da'i komunitas Sunda menjadikan matan Syubul iman Karya Ibn al-Hajar Al Asqolani sebagai rujukan dalam hal etika pergaulan, kitab Taubihul Gofilin karya Abdul Wahab As-Syarani, dan kitab al-Kasyfu wat-Tabyin fi Ghururi alKhafi Ajmain karya Imam Al-Ghazali.

Mengacu pada sumber rujukan pesan dakwah di komunitas Alawi, maka 
prinsip toleransi, dan menghargai kebedaan dan keberagaman umat dakwah sebagai bagian dari sunatullah dan etika dalam berukhuwah universal. Corak khusus dalam hal halaqah duee sebagai salah satu macam

dakwah internalisasi ajaran, pesan dakwah yang mereka sampaikan adalah menyeru pada karya leluhur Arab Alawi, misalnya kitab Syarb Ratib al-Hadad yang berjumlah 526 halaman karya al-Habib al-'Alamah Ahmad bin Al-Hasan bin Abdullah bin Ba"lawi al-Hadad Ba"lawi, di dalam kitab ini disajikan teks dalam syarah dari Ratib al-Hadad, secara terpisah juga ada Ratib yang disusun oleh Habib Ali Al-Idrus ini dibaca bergantian dalam halaqah du'a dapat dipilih salah satu dua macam kitab atau dapat dibacakan dari keduanya. Dan dilengkapi dengan Hižb alFatah dan Hið̧b al-Nashr.

Sisi perbedaan pemahaman atau terdapat khilafiyah memang muncul di anatara 3 (tiga) komunitas ini. Masalah khilafiyah ini antara lain dalam masalah: Pertama, jumlah raka' at shalat tarawaih pada bulan ramadhan ada yang 23 rakaat, 11 rakaat, 40 rakaat ada yang 100 rakaat. Kedua, dalam menentukan awal bulan ramadhan dan hari raya idul fitri ada yang penentuannya menggunakan metode hisab (perhitungan menurut ilmu falaq atau astronomi), ada yang menggunakan metode ru'yah (penglihatan mata dan dibantu alat teleskop) atas posisi hilal untuk menentukan awal bulan ramadhan. Ketiga, ajaran tentang kaifiyat du ${ }^{\text {ee }}$, ada yang materinya hanya ada dalam Al-Quran dan As-Sunah, yang kemudian disebut alma'tsurat dan yang diambil dari isyarat Al-Quran dan As-Sunah, dan ada yang hasil ijtihad para ulama. Keempat, ajaran tentang wasilah dalam berdo'a.

Materi ta'lim di komunitas Arab Alawi terdiri dari Aqidah, ibadah, akhlak dan muamalah versi pemahaman ahlu sunnah wal jama'ah yang disampaikan oleh Mu'alim/penceramah yaitu para habib. Diantaranya: Habib Abdullah Husain al Athas, Habib Muhsin bin Abdul Qadir, Habib Hasan Sahab, Habib Muhammad bi Aqil, Habib Abdullah As-Segaf, Habib Abdurrahman Shahab.

Pesan dakwah bagi komunitas Arab Irsyadi yang disampaikan oleh

para da'inya, berbeda dengan pesan dakwah yang disampaikan oleh da'i komunitas Sunda dan Arab 'Alawi. Perbedaannya dilihat dari corak pemahaman dan sumber rujukan yang digunakan, sebab bagi komunitas Arab Alawi ajaran islam sebagai pesan dakwah mesti mengacu pada ajaran murni yang tidak bercampur dengan tambahan-tambahan dari hasil ijtihad, apalagi yang bersumber dari uruf lokal. Mereka mengklaim sebagai penganut suni salafi, yaitu pemahaman islam yang murni, yang dicontohkan oleh sunah Nabi Muhammad SAW sebagai penafsiran dan pengamalan sumber utama ajaran islam, yaitu Al-Quran. Suni Salafi ini juga mengklaim

sebagai pengikut gerakan pembaruan dan pemurnian aqidah islam dan syariat dari produk bid'ah dan khurafat, yaitu penambahan dan penyimpangan dari ajaran murni yang bersumber pada Al-Quran dan As Sunah. 
Dalam aspek aqidah corak pemahaman komunitas Arab Irsyadi bersumber pada pemahaman Taqiyuddin bin Taimiyah, Ibn Qayim al Jawziyah, Muhammad bin Abdul Wahab, dan Syeikh Muhammad Abduh. Ajaran tauhid yang mereka anut dikategorikan pada Tauhid Rububiyah (keyakinan bahwa maha pencipta), tauhid uluhiyah (hanya kepaada Allah beribadah), dan tauhid sifat dan af'al (menurut isyarat yang termuat dalam Al-Asmaul Husna). Kitab utamanya antara lain kitab Syarh Ushulus-Salatsah karya Muhammad bin Abdul Wahab, dan kitab tauhid karya Syeikh Muhamad Abduh.

Dalam aspek ibadah, fiqih yang mereka jadikan sebagai pesan dakwah dan sekaligus sebagai rujukan pengamalan ibadah, mengacu pada kitab-kitab fiqih yang Struktur bahasanya berdasarkan hadits Nabi Muhammad SAW, bukan matan dan syarah hasil ijtihad seperti di kalangan komunitas Suni Khalafi dan komunitas Arab Alawi. Misalnya kitab fiqih karya Sayid Sabiq, Shahih Fiqih Sunah karya Abu Malik Kamal bin Sayid Salim. Oleh karenanya dalam praktik ibadah mahdhah, mereka berbeda pilihan misalnya mengenai jumlah shalat tarawih yang sebelas rakaat, adzan shalat jum'at yang satu kali, tidak ada muraqi (semacam protokol, yang mempersilahkan jalan dan khatib naik mimbar).

Termasuk kekhasan pesan dakwah bagi da'i komunitas Arab Irsyadi adalah mengenai teks du'a yang dibacakan, mereka mengikuti yang menurut pemahaman mereka sebagai yang matsurat (menurut contoh tuntunan Nabi Muhammad SAW), misalnya bacaan du' a setelah shalat tidak diterjamaahkan, cukup membaca tasbih, tahmid, dan takbir, masing-masing 33 kali. Begitu juga, mereka dalam hal berdu'a tidak ada tawasulan, bagi mereka hanya tawasul dengan amal shalih yang dilakukan oleh diri sendiri, dan menyebut amal shalih yang telah dilakukannya itu. Kegiatan meziarahi makam-makam kramat seperti yang dilakukan oleh suni khalafi, mereka tidak melakukannya. Walaupun demikian, mereka dapat memahami dan menghargai perbedaan dan keberagaman paham yang dianut oleh komunitas di luar kominitas Arab Irsyadi. Mengenai rujukan aspek ajaran akhlak yang berdasarkan pada hadits-hadits shahih menurut yang mereka pilih, misalnya bab-bab akhlak dan adab yang ada dalam kitab Shahih bukhari dan Shahih Muslim.

Komunitas Arab Alawi ketika bergaul dengan komunitas Sunda menggunakan bahasa Sunda, penggunaan bahasa Arab hanya terbatas sesama Arab Alawi (Arab 'Aamiyah). Bahasa Arab hanya dipakai berkomunikasi di internal sesama arab Alawi dengan arab Irsyadi. Kadang-kadang tutur kata dalam obrolan ketika menggunakan bahasa Indonesia atau Sunda, terkandung kata-kata atau ucapan bahasa Arab.

\section{Unsur Metode dan Media Dakwah}

Metode yang digunakan ketiga komunitas ini mencakup: khithabah (media lisan), kitabah (media tertulis), dan takwin (pengkaderan). Metode kaderisasi (takwin) 
hafidz Al-Quran komunitas Sunda menyelenggarakannya dengan mengambil tempat terpisah dari masjig agung At-Thohiriyah, yaitu Pesantren Tahfidz AlQuran yang berlokasi di Cisarua Bogor.

Wasail atau media dakwah yang digunakan oleh da'i komunitas Sunda, Arab Alawi dan Arab Irsyadi, juga terdapat banyak kesamaan dari pada perbedaannya. Hal yang berbeda dalam menggunakan wasilah ma' nawiyah (media immateri) berupa Syamail al-Du'at (gaya dan gestur penampilan sosok para da'i) ketika berinteraksi dengan mad'u, masing-masing mempunyai ciri khas yang berbasis pada uruf (sistem norma dan etika) berpakaian sebagaimana yang sudah dimaklumi oleh masing-masing komunitas, misalnya dalam hal berpakaian da'i komunitas Sunda, Arab Alawi dan Arab Irsyadi. Termasuk kategori wasilab ma'nawiyah adalah menggunakan gelar atau sebutan kehormatan sedabimana dijelaskan sebelumnya.

Media lisan yang melekat dengan diri para da'i, sama-sama digunakan. Masjid, madrasah dan sekolah ketiga komunitas tersebut, sama-sama menjadikannya sebagai wasilah madiyah (media berupa fisik/materi) dakwah, walaupun bentuk dan gaya bangunan fisiknya berbeda-beda menurut kecenderungan dan pilihan estetika yang mereka pilih dan mereka sepakati. Media cetak (media tulisan) juga sama-sama digunakan oleh ketiga komunitas. Media elektronik berupa pengeras suara, juga sama-sama mereka gunakan. Dengan demikian, adanya kesamaan uslub dan kesamaan wasilah, serta nuansa perbedaan wasilab ma'nawiyah menjadi perekat keharmonisan dan kondusivitas kehidupan keagamaan diantara ketiga komunitas. Situasi dan kondisi ini, menjadi saling menguntungkan bagi semua pihak, juga bagi pihak pemerintah setempat. Upacara-upacara ritual keagamaan komunitas Sunda dan Arab Alawi sebagai media dakwah dan

merealisasikan ajaran silaturahim diantara sesama muslim walaupun berbeda pandangan yang dipilih oleh masingmasing komunitas menjadi perekat kesatuan dalam keragaman, dan keragaman dalam kesatuan sebagai umat islam di wilayah Empang Kota Bogor, yaitu upacara tahlilan, marhabaan, upacara perkawinan, upacara syukuran, upacara peringatan hari besar Nasional dan kegotong royongan dalam mengatasi problem lingkungan hidup.

Wasilah Ma'nawiyah dan Madiyah, juga terlihat jelas dalam pelaksanaan Shalat Wajib 5 waktu dan Rawatiban dilaksanakan dengan Imam bergiliran dari Imam Etnis Sunda, Arab Alawi dan Irsyadi. Shalat Sunat Tarawih, di mesjid agung menganut jumlah 23 rakaat tetapi yang Arab Irsyadi dan Sunda yang biasa mengikuti rakaat tarawih 11 rakaat meninggalkan berjamaah setelah selesai 8 rakaat kemudian melanjutkan dengan shalat witir di mesjid atau di rumahnya masingmasing.

Di sela-sela setiap 2 (dua) rakaat tarawih secara berjamaah dibacakan bacaan tertentu dan shalawat. Sedangkan Ta'lim Jumhur (Adda'wah Bitta'lim) 
Ceramah singkat setelah berjama'ah penceramah bergantian. Ta ${ }^{\text {eclim Mingguan }}$ dengan Mubaligh dari: Jama'ah Tabligh, Hizbut Tahrir Indonesia (HTI), Nahdlatul Ulama, Pimpinan DKM Athohiriyah. Jama'ah campur semua etnis muslim di Empang yang sempat hadir. Secara khusus ada ta'lim mingguan untuk ibu-ibu dengan penceramah/mubalighah $\mathrm{Hj}$.Siti Aminah bertempat di bangunan khusus di samping mesjid.

Arab alawi dan Sunda NU tahlilan 7 hari 7 malam. Arab Irsyadi dan Muhammadiyah tidak melakukan tahlilan. Wisata Ziarah juga menjadi wasilah lain. Hampir tiada hari tanpa ada yang ziarah, apalagi di saat-saat yang dipandang sebagai momentum spiritual. Penziarah ini berdatangan dari berbagai daerah, selain komunitas Arab Alawi adalah komunitas Sunda. Dari komunitas Sunda ini lebih banyak dan mayoritas terutama di bulan Rabiul 'Awal (bulan Maulud).

\section{PENUTUP}

Prinsip-prinsip dakwah multikultural yang diajukan perspektif dakwah multikultural, digunakan dan ditaati oleh komunitas Sunda, Arab Alawi maupun Arab Irsyadi. Prinsip-prinsip tersebut yaitu: saling memahami adanya perbedaan dan keragaman sebagai sunatullah, tidak menjadikan perbedaan sebagai aset konflik dan perpecahan, tetapi menjadikannya sebagai aset perekat kesatuan dalam keragaman dan keragaman dalam kesatuan, meyakini hakim tunggal yang memutuskan kebenaran mutlak atas segala perbedaan paham dan uruf dalam realitas kehidupan umat adalah hanya Allah SWT. Dan mereka dalam hal yang sama bekerja sama, dan dalam hal yang berbeda sama-sama kerja, menurut pilihan masing-masing komunitas.

Da'i komunitas Sunda, Arab Alawi, dan Arab Irsyadi memiliki kualifikasi sebagai da ${ }^{\text {ee }}$ yang kredibel dihadapan mad'u masing-masing, mad'u merespon positif terhadap kehadiran $\mathrm{da}^{\mathrm{ec}} \mathrm{i}$ masing-masing. Status kompeten keilmuan yang disimbolkan dalam bentuk gelar yang disandang oleh da'i masing-masing komunitas menjadi salah satu faktor terpenting citra da'i sebagai da’i, yaitu Kiayi, Ajengan, dan pak guru bagi da ${ }^{e c} i$ komunitas Sunda; Habib, Syarif, dan Sayid bagi da'i komunitas Arab Alawi, dan gelar akademik S1, S2, dan S3 bagi da'i komunitas Arab Irsyadi. Ketiga personal da'i dan ketiga komunitas itu pada suatu even tertentu tampil sebagai pembicara dihadapan semua mad'u dari ketiga komunitas. Da'i dari semua komunitas menghargai adanya perbedaan, dan keragaman yang ditunjukan dalam uruf masing-masing komunitas, dan dalam perbedaan yang dipandang kontradiktif, para da'i bersikap setuju dalam perbedaan.

Mad'u dakwah dari 3 (tiga) komunitas berbaur pada waktu dan tempat yang sama dalam event-event dakwah tertentu, dan berpisah menurut kelompok masing-masing pada waktu dan tempat yang berbeda dalam event-event dakwah 
yang khas bagi masing-masing komunitas. Hal ini adalah menjadi bagian yang sunatullah. Latar belakang mad'u beragam baik dari sisi umur, jenis kelamin, pendidikan, status sosial, ekonomi, ekspresi uruf, bahasa, dan etnik mad'u. Ini adalah penununjukkan heterogen homogenitas dalam keragaman tersebut adalah nilai universal kemanusiaan sebagai bagian dari makhluk Allah SWT, semua dari keturunan Bani Adam A.S, dan berfitrah diniyah ( berkeyakinan akan adanya maha pemilik alam semesta yang hanya kepadaNya menyembah dan akan kembali memperjuangkan amal baik dan jelek ketika di alam dunia, dan dalam alam akhirat nanti, yaitu alam keabadian di atas keabadian).

Pesan dakwah yang disampaikan dari ketika da'i komunitas ada yang sama dan ada yang khas berbeda. Menurut sumbernya semua sama, yaitu bersumber pada Al-Quran dan As-Sunah, bagi komunitas Arab Irsyadi tidak ditambah ijma dan qiyas kecuali bagi komunitas Sunda dan Arab Alawi. Warna dan corak pemahaman dari sumber tersebut sama-sama mengikuti paham suni atau Ablus Sunah Wal Jama'ah, namun demikian terdapat perbedaan dalam hal-hal tertentu yang merupakan perbedaan dari metodologi ijtihad yang digunakan dantara mereka, sehingga muncul kategorisasi Suni Salafi dan Suni Khalafi, misalnya dalam aqidah, ibadah, dan tata cara berdo"a bagi suni salafi ada perbedaan dengan Suni Khalafi namun demikian mereka tetap saling memaklumi dan menghargai perbedaan tersebut, begitu pula dalam referensi kitab yang digunakan ada

perbedaan antara suni salafi dengan suni khalafi, suni salafi dianut oleh komunitas Arab Irsyadi sedangkan suni khalafi dianut oleh komunitas Sunda dan Arab Alawi.

Wasilah ma"nawiyah dan wasilab madiyah dalam proses menyampaikan dan melewatkan pesan dakwah, juga terdapat kesamaan diantara mereka, namun ada yang berbeda bagi komunitas Arab Irsyadi, yaitu tidak menggunakan wasilah dakwah (media) yang menurut klaim mereka termasuk bid'ah dan khurafat. Sedangkan dalam penggunaan uslub (metode) dakwah, juga terdapat kesamaan diantara tiga komunitas tersebut, masing-masing membasiskan uslubnya pada prinsip hikmah, mauidzah hasanah dan mujadilah hasanah, misalnya, semua masih menggunakan cara ceramah, khithabah diniyah, tausiyah, bahasa tulisan dan perbuatan. Aspek bahasa lisan dakwah tidak menjadi hambatan komunikasi dakwah antara da'i dengan mad'u masing-masing komunitas, juga antar komunitas. Mereka mengerti dan mampu menggunakan bahasa Sunda dan Indonesia dalam menerjemahkan ajaran agama islam sebagai pesan dakwah yang berbahasa Arab.

\section{DAFTAR PUSTAKA}

Khalil, S. A. (1428 H/ 2007 M) At-Tasamuh fi al-Islam. Cet ke-5. Damaskus: Dar 
al-Fikr.

Khalil, S.A. (2012). Atlas Penyebaran Islam. Jakarta Timur: Al Mahira.

Al Faruqi, I.R. (1988) Tauhid. Bandung: Penerbit Pustaka.

Al-Hadad, A. A. A. (1392 H). Meraib Kebahagiaan Sejati: Jalan Hidup Para Nabi dan

Orang Suci. Diterjemahkan dari Al-Fushul Al-Tlmiyyah wa Al-Ushul Al-

Hukmiyyah oleh Muhammad Bagir. Cet ke-2. Bandung: Al Bayan Mizan.

Arnold, T.W. (1970). Ad-Da'wah ila al-Islam: Babts fi Tarikh Nasyr al-'Aqidab alIslamiyyah. Diterjemahkan dari The Preaching of Islam: a History of the propagation of the Muslim Faith oleh Hasan, I. H., Abidin, A. M. dan Bahrawi, I. Cet ke3. Kairo: Maktabah anNahdhah al-Mishriyyah.

Azis, A.M.N. \& Zainab, S. (2018) Tantangan Dakwah Pada Masyarakat Mulikultural di Kalimantan Tengah dalam Wardah. 19 (2). 124-125 diakses April 2016 dari http://lib.ui.ac.id/file?file=digital/127912D\%20\%2000962\%20Perempuan\%20Arab\%20Literatur.pdf.

Diakses April 2016 dari http://www.rabithah-alawiyah.org/id/kontribusikomunitas-arab-di-jakarta-abad19-dan-awal-abad-20-masehi/.

Garna, J.K. (2009) Metode Penelitian Kualitatif. Bandung: Primaco Akademika.

Hamka (1961) Sejarah Umat Islam, Bukit Tinggi-Jakarta: NV Nusantara.

Jailani, I. A. (2014) Dakwah dan Pemahaman Islam di Ranah Multikultural dalam Walisongo. 22 (2). 413-416.

Marfu'ah, U. (2017) Strategi Dakwah Berbasis Multikultural dalam Islamic Communication Journal. 2 (2). 147.

Muhyiddin, A. dkk. (Eds). (2014) Kajian Dakwah Multiperspektif. Bandung: Remaja Rosdakarya.

Nawawi, N. (2012). Dakwah dalam Masyarakat Multikultural dalam Komunika. 6 (1).

Rosidi, R. (2017) Metode Dakwah Masyarakat Multikultural di Indonesia dalam Bina Al-Ummah. 12 (1).

Saifulah, S. (2014). Dakwah Multikultural Pesantren Ngalah dalam Meredam Radikalisme Agama dalam Islamica: Jurnal Studi Keislaman. 8 (2), 435-436.

Suparman, H. (2017) Multikultural dalam Perpektif Alquran dalam Al Quds: Jurnal Studi Alquran dan Hadits. 1 (2).185-187, 194.

Tim Raudhah. (2009) RATIB (Arab-Latin-Terjemab). Jakarta: Raudhah Pres

Turhamun, T. (2016). Multikulturalisme sebagai Realita dalam dakwah dalam Komunika:Jurnal Dakwah dan Komunikasi. 10 (1). 154-156

Zuhdi, M. H. (2012). Dakwah dan Dialektika Akulturasi Budaya dalam Jurnal Religia. 15 (1). 